\title{
Flexibility in collective wage bargaining in New Zealand: facts and folklore
}

\author{
Raymond Harbridge*
}

Prevailing folklore in New Zealand has it that wage bargaining outcomes are unduly inflexible. Implicit contract theory suggests that while wages may be sticky and somewhat rigid within a single wage round, stickiness will diminish over time as wages become responsive to outside economic forces. This paper examines the hypothesis that the stickiness of wage settlements diminishes over time and develops 4 criteria for testing that hypothesis. Data for all settlements registered with the Arbitration Commission since 1984 are used. Analysis of the data indicates that despite folklore to the contrary, a very important degree of wage flexibility exists.

\section{Introduction}

The question of whether wage flexibility exists in New Zealand's collective bargaining system has been the subject of considerable speculation, claim and counterclaim in policy debates about whether further de-regulation of the New Zealand labour market is required (Dannin, 1990). Some of the proponents of further flexibility have relied heavily on folklore rather than facts, and in the quite recent past some of the "statistics" quoted have been badly astray. The OECD recently made the claim that in the 1987-88 wage round "90 percent of subsequent wage settlements were clustered around 1 percentage point of the 7 percent metal trades award" (OECD, 1989). A senior employer negotiator, Tom Kiely, had earlier made an identical claim (Kiely, 1988). In fact, 67 percent of all settlements lay within the one percent either way figure, and 69 percent of awards fell in the same range in that particular wage round (Harbridge and McCaw, 1990a). An industrial mediator (Grills, 1988) made a similar claim for the same wage round stating that "two out of three settlements were reached between 7 and 8 percent" when in fact 2 out of 3 settlements were reached between 6 and 8 percent (Harbridge and McCaw, 1990a). Other examples abound, but the overall impression given is that wage settlements conform to a very rigid pattern.

The need for an accurate statement of fact regarding wage flexibility is therefore apparent, as is the need for the development of criteria for evaluating the extent of wage dispersion. Any framework for examining wage flexibility needs to take a number of institutional and legal factors into account. Schultze (1985) explains the notion of the "stickiness" of wages in terms of implied contract theory. Workers are not like other

Industrial Relations Centre, Victoria University of Wellington. I am particularly grateful to Brian Easton, Colin Hicks, Fraser Jackson, Stuart McCaw, Ray Taylor and the journal's editors and referee for their ideas on measuring dispersion, assistance with the statistics, and their helpful comments on earlier drafts of this paper. An earlier version was presented to the 5th biennial Association of Industrial Relations Academics of Australia and New Zealand conference, Melbourne, 4 - 7 July 1990. This research has been supported by the New Zealand Planning Council, the Faculty of Commerce and Administration and the Internal Grants Committee of Victoria University of Wellington. 
economic agents, in that they acquire non-transferable employer-specific skills and the cost of acquiring those skills may have been borne by the employer; workers acquire experience on the job; and additional search, transition and moving costs are incurred by the employer when a worker leaves. In these circumstances, wages are fixed, in part, by a "looking over the shoulder" approach. In the absence of precise information about relevant economic factors, and because the employer does not want to lose a committed, trained workforce, the employer and union parties to negotiations tend to look at what others have agreed in their bargaining - this being the "implicit contract". Accordingly, under this theory, wage fixing outcomes would not be expected to be particularly flexible in the short term. Flexibility may however be expected over time as the labour market adjusts to extemal pressures.

In the New Zealand context, Easton (1987) has developed Schultze's views that implicit contract theory suggests an inherent stickiness in wage relativities. Institutional wage setting features are reviewed, particularly as they relate to downwards flexibility. Minimum wages are established either under the Minimum Wage Act 1945 or in awards and collective agreements negotiated under the Labour Relations Act 1987. There are some serious constraints on downwards flexibility, particularly within the award bargaining system. First, awards already contain comparatively low wage rates. For example, in the 1988/89 wage round, 30 percent of all awards contained a minimum adult rate of $\$ 280$ or less per week and 50 percent contained a minimum adult rate a rate of pay of $\$ 295$ or less per week. Second, there is a genuine constraint at the zero increase level if employers claim a lower wage settlement than that currently applying in the existing settlement, then unions would refuse to reach settlement. In that event, the existing award would run its course as provided for under the Labour Relations Act and wages would continue at their current levels. Third, the lower bounds of flexibility are constrained by the fixture of the minimum wage as set from time to time under the Minimum Wage Act. The Minimum Wage Act plays an important role in maintaining minimum award rates. For example, in the 1988/89 wage round there were 13 awards registered that contained an adult rate of pay lower than the then minimum wage of $\$ 235$ per week. More recently, when the Government adjusted the minimum wage to $\$ 245$ per week as from 17 September 1990, there were 31 awards already registered as part of the 1989-90 wage round which contained an adult rate of pay lower than the new minimum wage. The wage rate set under the Minimum Wage Act takes precedence over any rate set in an award and the Arbitration Commission indicates to union and employer parties any pay rates in proposed awards and collective agreements that would breach the Act's provisions.

In addition, if inflation is comparatively low - say at 4 percent per annum - then the degree of possible wage dispersion is limited (for the sorts of reasons just outlined) to increases from a zero percent increase at the lower end of the scale to increases around or slightly more than 4 percent. If however, inflation is comparatively high - say 15 percent - then the degree of dispersion still is bounded at the lower end of the scale by a zero percent increase, but the range of settlements is likely to extend up to and above 15 percent. Clearly a far wider range of dispersion is available in times of high inflation.

Inflation is most frequently measured by the consumers price index (CPI) and the producers' price index (PPI). CPI is limited as a comparator to wage increments as other income related factors are involved. A more useful measure of inflation is PPI (inputs). PPI is a better comparator for wage increases than CPI, as it measures the cost increases of goods and services, other than wage costs, to producers (Department of Statistics, 1990). Further, PPI is useful for it is calculated on an ex-GST basis, thus providing a statistic that can be compared with wage movements which were not themselves intended to incorporate GST (Dickson, 1989). It is worth observing that the use of CPI and PPI to deflate wages reflect two different perceptions of the role of wages. Easton (1986, p.31) describes these different perceptions as "wages-as-income" and "wages-as-costs". 
Wells and Bertram (1983, p.72) make a similar distinction, using the terms "real-incomewage" and "real-product-wage".

\section{Terminology and methodology}

The wage data presented in this paper commence with all settlements registered with the Arbitration Commission after 1 December 1984 - the end of a government imposed wage freeze. The data presented are grouped within the 5 consecutive wage rounds from $1984 / 85$ to $1988 / 89$. While documents are negotiated and settled at different points through each wage round, there remains a clear pattern of documents being negotiated in the September to September year, with a majority of settlements containing wage increments applicable from at least the month of February.

The data presented do not represent all settlements negotiated and registered with the Arbitration Commission for each wage round. This is because the data measure change from one wage round to another. This means, for example, that settlements that are new and that have been registered with the Commission for the first time are excluded from consideration. Also excluded are settlements that have been renegotiated long after their nominal expiry. The other main category of exclusion of wage settlements are those that were for flat monetary increases rather than percentage increments. These settlements were excluded as the conversion of a flat monetary increase to a percentage increase produces a range of percentage increases rather than a single score, and the incorporation of ranges of percentage increments into the dataset was not possible.

That the data are measuring change from one wage round to another is important for it introduces significant biases in the level of flexibility observed. Important levels of change in the tails of the distribution of the settlements are not being recorded in the data presented in this paper. It has been informally observed by the author that the new settlements represent wage levels and increments generally well above the pattern of settlements for any particular wage round. Accordingly the exclusion of a large number of new settlements is almost certainly excluding settlements that represent upwards flexibility, found in the high tail of the distribution of settlements, being wage increments well above the mean wage settlement. In the low tail of the distribution, the data does not record those documents that have not been renegotiated from one round to the next and that are, in some cases, on the way to lapsing altogether. In considering the outcomes of the 1988/89 wage round, it is argued elsewhere that some of the award negotiations that did not lead to a settlement were more important in any overall view of structural bargaining changes than were those negotiations that did lead to a registered settlement (Harbridge and McCaw 1990b). In the 1988/89 wage round, there were 25 awards that were not renegotiated from either of the previous two wage rounds even though the unions concerned had attempted to do so. This represents nearly 10 percent of all awards registered in the 1988/89 wage round. Employer intransigence was given as the reason for non-settlements by the unions involved.

Five statistics which aid interpretation of the degree of dispersion within wage rounds have been selected - first the mean wage increase, second the standard deviation, third the semi interquartile range, fourth the "Bradford" statistic, and fifth skewness. Each of these variables requires some explanation. In the following tables the number of settlements, $\mathrm{N}$, represents the number of settlements where the wage comparison between wage rounds was possible. Necessarily, $\mathrm{N}$ represents less than the total settlements within the wage round but contains an important number of settlements. In the 5 wage rounds examined, $\mathrm{N}$ represents between 80 and 90 percent of all registered awards and between 65 and 75 percent of all other types of registered settlements (voluntary collective agreements, composite agreements, agreements and composite awards). 
The mean wage increase is the mean of the annualised wage increment calculated for each settlement. Our method of calculating the annualised wage increment takes into account a number of factors - whether the settlement was fully backdated to the expiry of the predecessor settlement; the term of the settlement if the term was for other than 12 months; and whether the settlement was stepped i.e. increased more than once during the life of the settlement. A discussion of the theoretical and mathematical issues involved is available in Ansell, Brosnan and Harbridge (1990). The standard deviation presented is an important measure of dispersion around that mean. Taking the mean and the standard deviation together, the wage data can be described in terms of the mean wage settlement and in terms of the average variation from that mean within each wage round.

The semi-interquartile range is the range in which the middle 50 percent of settlements fall. It is a useful measure of dispersion in that it excludes the difficulties of comparison that occur when the tail of the distribution is extreme - in one wage round for example, the mean wage increment was around 7.5 percent but there was a spread of settlements ranging from 0 percent to 22.5 percent. In any averaging process these extremes can distort the value of the mean in an unrepresentative way (Van Dalen, 1962, p.341).

The "Bradford" statistic is the percentage of settlements that fall within one percent either way of the percentage increment agreed in the Metal Trades Award negotiations. This statistic is named after the former Director of Advocacy at the New Zealand Employers Federation, Max Bradford, who persistently claimed in the early 1980s, that 90 percent of settlements were within one percent of the increase applied to the Metal Trades Award (see Bradford 1982; 1983, p.19). The "one percent either way" measure caught on (viz the OECD, Kiely etc) and it was felt appropriate to credit Bradford for developing this measure of dispersion.

Skewness is a useful measure of the shape of the distribution of the settlements. In this case, a distribution is skewed if the wage settlements bunch to one side of the mean wage settlement extending a long tail to the other side. If the tail extends to the right the distribution is said to be positively skewed - indicating a considerable spread of settlement in excess of the mean settlement and a bunching of settlements below or very close to the mean settlement. The distribution of settlements is negatively skewed if the tail extends to the left - conversely indicating a spread of settlements lower than the mean and a bunching of settlements above or close to the mean wage settlement.

In these contexts, 4 criteria are proposed to evaluate the extent of wage flexibility. The first criterion is a direct comparison with PPI as a measure of inflation. Should wage bargaining outcomes regularly exceed inflation as measured by PPI then downwards flexibility will be taken to be absent. The second criterion is designed to measure the extent of stickiness of wage settlements within each wage round. For the reasons outlined earlier, it is expected that wage increases will demonstrate a certain degree of stickiness, particularly in the short term and within a single wage round. Although there are no theoretical reasons to expect 90 percent of settlements to fall within one percent of the Metal Trades settlement, the influence of Bradford's claim upon policy debate was sufficiently important to warrant paying particular attention to it. The criterion selected to measure whether this expected stickiness is flexible or inflexible is whether the Bradford statistic reported is less than the usually quoted figure of 90 percent. If the Bradford statistic in each wage round is lower than 90 percent then flexibility will be taken to be present.

The third and fourth criteria are designed to measure the extent of stickiness in wage settlements in the medium term - in this case 5 wage rounds. It is reasonably expected that wage settlements over a 5 year period will have some opportunity to adjust to external economic factors and that some of the flexibility achieved within each wage round will be accumulated. If wage stickiness is to diminish over time, comparatively low settlements in one wage round will in successive wage rounds continue to settle at comparatively low figures. Conversely, a comparatively high settlement in one round 
would be expected to be followed by comparatively high settlements in later wage rounds. On the other hand, if wage stickiness is to persist over time, then low settlements in one round will catch-up in later rounds and that high settlements will be held-back in later rounds. Accordingly, the second criterion is the skewness statistic and the third dispersion criterion is the semi-interquartile range statistic. It is hypothesised that there will be stickiness within each wage round but that it will diminish across wage rounds. If this hypothesis is true then the skewness statistic will be positive and possibly quite large for the wage settlement data in individual wage rounds, but will be comparatively small (approaching zero) over the 5 wage rounds considered in this paper. A small skewness statistic over time would confirm the hypothesis that wage stickiness diminishes over time as some settlements continue to do better (or worse) than others. The semi-interquartile range statistic could also confirm this hypothesis. If wage increments remained sticky over time then settlements are being 'held back' or are 'catching-up' in successive wage rounds. In an individual wage round, the semiinterquartile range statistic would then be expected to show a small and limited range within which settlements fell. Over time however, diminishing wage stickiness would be indicated by a larger semi-interquartile range statistic - being evidence of low settlements continuing to settle low and high settlements continuing to settle high.

\section{Wage round data 1984-1989}

Data for the 5 successive wage rounds from 1984/85 to 1988/89 are presented according to the type of settlement registered with the Arbitration Commission. In terms of the number of workers covered by the different types of settlements, awards are far and away the most important type of settlement. Accordingly, the data is presented first, for awards only, and second, for all other registered non-award settlements (agreements, composite agreements and composite awards). 1

The data presented in both tables present a number of important findings. First, there is greater dispersion of wage increases in non-award settlements than in awards. This is shown by the finding, in successive wage rounds, that the standard deviations are smaller for awards than non-award settlements; that (with the exception of the 1986/87 wage round) the semi interquartile ranges are greater for non-award settlements than for awards; and that the Bradford statistic is smaller for non-award settlements than for awards $^{2}$. Second, dispersion was greater in those wage rounds where a larger wage increase applied, than in those wage rounds where the wage increase was comparatively

1 In the 1984/85 wage round, the percentage increment presented reflects the percentage change recorded by the parties in the memorandum attached to the settlement as required by a 1984 amendment to the Industrial Relations Act 1973. That percentage has been annualised as outlined earlier. The existence of these memoranda in the 1985/86 and $1986 / 87$ wage rounds has enabled the incorporation of data for new awards thus explaining the increase in " $\mathrm{N}$ " in the 1986/87 wage round data for award settlements. As only awards were required to include such a memorandum, the data presented contain only 7 more documents in non-award settlements than for awards. " $N$ " for non-award settlements has increased in the $1986 / 7$ and $1988 / 89$ wage rounds. This is because many settlements registered for the first time have been successfully traced to a predecessor settlement, thus allowing the calculation of the annualised percentage wage change. The $\$ 8$ per week General Wage Order of April 1984 is not included in the data.

2 That the "Bradford statistic" is smaller in this data set than that stated by Bradford and his successors at the New Zealand Employers Federation can be partly attributed to the finding that the Employers Federation dataset excludes settlements not negotiated by Employers Federation advocates. This suggests that greater flexibility in settlements exists when the Employers Federation is not involved in the negotiating process - a hypothesis worthy of further investigation. 
low. This suggests the paradox of inflation - when there is high inflation the greatest flexibility and opportunity for adjustment occurs. It is useful to have a variety of alternative measures available to judge dispersion as is shown by the data for periods of high inflation. In the $1985 / 86$ wage round for example, a period of comparatively high inflation, the dispersion as measured by the semi-interquartile range is quite small yet the dispersion as measured by the Bradford statistic and the standard deviation is large. In that particular period of high inflation there was a bunching of settlements around the mean wage settlement but an important number of both award and non-award settlements dispersed well around the mean as is shown by a Bradford statistic of 74.4 percent and the largest standard deviation observed of all 5 wage rounds for both award and non-award data.

Table 1: Variation in percentage wage increments in registered awards in successive wage rounds :1984/85 - 1988/89

\begin{tabular}{|c|c|c|c|c|c|}
\hline & $1984 / 85$ & $1985 / 86$ & $1986 / 87$ & $1987 / 88$ & $1988 / 89^{2}$ \\
\hline $\mathrm{N}$ & 260 & 233 & 274 & 223 & 206 \\
\hline CPI \% & 9.4 & 15.5 & 10.6 & 16.1 & 5.6 \\
\hline PPI (Inputs) \% & 8.1 & 15.0 & 3.2 & 8.3 & 4.9 \\
\hline Mean increase \% & 8.5 & 15.8 & 6.9 & 7.5 & 4.0 \\
\hline Standard deviation \% & 1.9 & 2.7 & 1.1 & 2.0 & 0.9 \\
\hline Semi interquartile & & & & & \\
\hline range $\%$ & $7.7-8.5$ & $15.3-15.9$ & $6.0-7.4$ & $7.0-8.0$ & $3.8-4.1$ \\
\hline 'Bradford' statistic \% & 84.2 & 74.4 & 89.0 & 69.1 & 89.3 \\
\hline Skewness & 6.3 & 3.0 & 3.7 & 2.9 & 0.5 \\
\hline
\end{tabular}

Note a Includes state sector documents previously issued as determinations under the State Services Conditions of Employment Act 1977.

Table 2: Variation in percentage wage increments in non-award settlements in successive wage rounds: 1984/85 -1988/89

$1984 / 85 \quad 1985 / 86 \quad 1986 / 87 \quad 1987 / 88 \quad 1988 / 89$

$\begin{array}{lrrrrr}\text { N } & 7 & 144 & 283 & 257 & 274 \\ \text { CPI \% } & 9.4 & 15.5 & 10.6 & 16.1 & 5.6 \\ \text { PPI (Inputs) \% } & 8.1 & 15.0 & 3.2 & 8.3 & 4.9 \\ \text { Mean increase \% } & 9.4 & 17.2 & 7.8 & 8.0 & 4.3 \\ \text { Standard deviation \% } & \text { NA } & 5.3 & 2.8 & 3.7 & 1.4 \\ \text { Semi interquartile } & & & & & \\ \text { range \% } & \text { NA } & 15.4-17.4 & 6.9-8.0 & 6.9-8.2 & 3.9-4.6 \\ \text { 'Bradford' statistic \% } & \text { NA } & 53.5 & 68.2 & 60.6 & 81.8 \\ \text { Skewness } & \text { NA } & 1.9 & 5.5 & 4.3 & 2.4 \\ \end{array}$


Third, the mean percentage increases for non-award settlements are greater than for the mean percentage increases for awards - again confirming a previously reported finding that awards are settled for lower percentage wage increases than are agreements, composite awards and composite agreements (Harbridge, 1988; Harbridge and McCaw, 1989). Fourth, the distribution of both award and non-award settlements is positively skewed indicating considerable flexibility exists in the upper range of settlements. Fifth, mean wage increments are lower than inflation as measured by CPI and have not been adjusted to compensate for the implementation of GST. Sixth, mean wage increases were higher than PPI (Inputs) for the 1984/85, 1985/86 and 1986/87 wage rounds but have been lower in the 2 wage rounds (1987/88 and 1988/89) negotiated under the Labour Relations Act 1987.

All registered settlements have been tracked through successive wage rounds to identify wage dispersion over time. This has been achieved by the development of a wage index - set at 1000 at the end of the wage freeze in December 1984. Actual nonannualised increments in successive settlements have been multiplied onto this base. The mean percentage increases in awards and in non-award settlements, along with the standard deviations and the semi interquartile ranges, are presented in Table 3.

Table 3: Variation in wage increments between $1984 / 85$ and 1988/89 by document type.

$\mathrm{N}$

CPI \%

PPI (Inputs) \%

Mean wage increase \%

Standard deviation \%

Semi interquartile range \%

Skewness
262

65.7

41.3

40.2

3.6

$37.8-41.7$

0.3
374

65.7

41.3

43.8

8.9

$39.6-44.4$

Awards have been increased on average by 40.2 percent while non-award settlements have increased on average by 43.8 percent. The dispersion as measured by the standard deviation is much greater for non-award settlements than it is for award settlements. Similarly, the semi interquartile range for non-award settlements is greater than for awards - representing about 4 percent for award settlements and nearly 5 percent for non-award settlements when taken over the five wage rounds since 1984. Non-award settlements are positively skewed indicating a small degree of upwards flexibility in those types of settlements. The pattern for award settlements taken over the 5 years is of interest. Skewness is almost zero indicating that cumulated award wage settlements are evenly distributed around the mean wage increase over that period. Wage increments for awards and non-award settlements have not kept pace with inflation as measured by CPI and largely this again is because the effects of GST have not been compensated for. Mean wage increments for awards have fallen about one percent below PPI (Inputs) over the 5 wage rounds but mean wage increments for non-award settlements are about 2.5 percent ahead on the PPI for the same period. 


\section{Are wage bargaining outcomes flexible?}

Before reaching any conclusions about the extent of wage flexibility in New Zealand's collective bargaining system, an important caveat on those conclusions needs to be stressed. As noted earlier, the data understate the degree of flexibility because they necessarily exclude a category of settlements that bunch in the upper and lower extremes.

The question remains - Are wage bargaining outcomes flexible? Four criteria for judging flexibility have been proposed - comparison with inflation as measured by PPI; whether the Bradford statistic is less than 90 percent; whether the semi interquartile range is relatively higher for the period 1984-1989 than for the separate wage rounds; and whether the skewness statistics are relatively lower for the period 1984-1989 than for the separate wage rounds.

The comparison with inflation as measured by PPI indicates that wage costs have not increased at a rate faster than other costs of production. Award increases are, on average, approximately one percent lower than PPI over the 5 years 1984-1989 while non-award increases are on average, about 2.5 percent higher than PPI. This indicates that award and non-award settlements are not inflexible, in that they are settled for increases that reflect other production costs.

There is important evidence of flexibility in wage settlements within each wage round using the criteria chosen. This flexibility is greater than that generally expected and is important in itself. The flexibility is demonstrated by the finding that the Bradford statistic is always smaller than the 90 percent claimed by Bradford himself. There are 2 wage rounds, $1986 / 87$ and $1988 / 89$, when the Bradford statistic is very close to 90 percent for awards alone. However the Bradford statistic is always much lower than 90 percent for non-award settlements and in 3 wage rounds the Bradford statistic is much lower than 90 percent for awards.

There is also important evidence of flexibility in wage settlements when examined over the period 1984-1989. The flexibility observed within a single wage round can be shown to increase over time. The criterion proposed for measuring flexibility over time was an examination of the semi interquartile range and skewness statistics. Diminishing wage stickiness would be shown by a comparatively low skewness statistic over time and a comparatively high semi interquartile range statistic. Within any individual wage round, the semi interquartile range is never greater than 1.4 percent for award settlements and 2.0 percent for non-award settlements. Over the period 1984-1989 the semi interquartile range is 3.9 percent for awards and 4.8 percent for non-awards. The semi interquartile range is then large in the medium term supporting the hypothesis that wage stickiness is diminishing over time. The skewness statistic for award settlements is lower over the period 1984-1989 than the skewness for award settlements in any individual wage round, again supporting the hypothesis that wage stickiness is diminishing over time. The skewness statistic is positive and not so small for non-award settlements over the period 1984-1989. This indicates that non-award settlements that have settled high in one wage round have continued to settle at high levels in subsequent wage rounds, but that low settlements have tended to catch up. The overall conclusion that must be reached from examining the skewness and semi interquartile range statistics is that wage stickiness is diminishing in the medium term and that an important degree of wage flexibility can be demonstrated over the period of the five wage rounds examined.

Despite the folklore to the contrary, the data presented in this paper indicate that, compared with measures of inflation, and within and between wage rounds, a very important degree of wage flexibility exists as an output of collective wage bargaining in New Zealand.

\section{References}


Ansell, J., Brosnan, P. and Harbridge, R. (1990) When is 3 plus 1 equal to 3.1? methods of examining wage settlements to determine their annual rate of adjustment. New Zealand journal of industrial relations. 15(1): 49-60.

Bradford, M. (1982) Real wages, inflation, unemployment and the New Zealand wage determination system. Paper to the New Zealand Association of Economists Conference, February.

Bradford, M. (1983) Issues of concern to employers. In R. Harbridge (ed) Industrial relations: issues of concern. Wellington, Industrial Relations Centre, Victoria University of Wellington.

Dannin, E.J. (1990) Examining employer associations' proposals for labour law reform: an American perspective. New Zealand journal of industrial relations, 15(2): 161-178.

Department of Statistics (1990) Hot off the press: producers price index - March 1990 Quarter. Wellington, Department of Statistics.

Dickson, I. (1989) Taxation. In S. Walker (ed) Rogernomics: reshaping New Zealand's economy. Auckland, Government Print Books.

Easton, B. (1986) Wages and the poor. Wellington, Allen and Unwin.

Easton, B. (1987) The labour market and economic liberalisation. In A.E. Bolland and R.A. Buckle (ed) Economic liberalisation in New Zealand. Wellington, Allen and Unwin.

Grills, W. (1988) Labour market flexibility: wage relativities under the Labour Relations Act 1987. New Zealand journal of industrial relations. 13(3): 157-166.

Harbridge, R. (1988) The way we were - a survey of the last wage round negotiated under the Industrial Relations Act 1973. New Zealand journal of business. 10: 48-65.

Harbridge, R. and McCaw, S. (1989) The first wage round under the Labour Relations Act 1987: changing relative power. New Zealand journal of industrial relations. 14(2): 149-167.

Harbridge, R. and McCaw, S. (1990a) Registered settlements and wage flexibility in the New Zealand private sector: 1984/85 - 1987/88. Journal of industrial relations. 32(2): 224-237.

Harbridge, R. and McCaw, S. (1990b) Emergent trends in wage bargaining in New Zealand: The 1988/89 wage round. Working paper 1/90, Wellington, Industrial Relations Centre, Victoria University of Wellington.

Kiely, T. (1988) How have composite, enterprise and industry bargaining been doing? Paper presented to the second annual conference on industrial relations, Auckland, New Zealand Institute for International Research, September 5-6.

OECD (1989) OECD Economic Surveys: New Zealand. Paris, OECD.

Schultze, C.L. (1985) Microeconomic efficiency and nominal wage stickiness. American economic review. 75(1): 1-15. 
Van Dalen, D.B. (1962) Understanding educational research. New York, McGraw-Hill.

Wells, G.M. and Bertram, G. (1983) The real wage controversy. In R.A. Buckle (ed) Inflation and economic adjustment. Wellington, Department of Economics, Victoria University of Wellington. 